\title{
ASSESSING CLAIMS RESOLUTION FACILITIES: WHAT WE NEED TO KNOW
}

\author{
Deborah R. Hensler*
}

I

\section{INTRODUCTION}

Most contemporary procedures for mass litigation were developed in a slow, reasoned fashion, as a result of professional study, scholarly discourse, judicial decisionmaking, and appellate review.' Claims resolution facilities, in contrast, are creatures of necessity. Each facility this symposium describes emerged from a specific litigation, and each reflects what the key participants perceived as the exigencies of the particular situation. All are the product of compromising the competing interests of parties, attorneys, judges, and other court actors. ${ }^{2}$ Those interests determined the broad outlines of each facility, as well as certain key features, such as the "first-in, first-out (FIFO)" processing rule of the original plan for the Manville Personal Injury Trust. ${ }^{3}$ Purely pragmatic considerations appear to have influenced other aspects of facility design and implementation. For example, despite the FIFO rule, the Manville Personal Injury Trust attempted to settle any case scheduled for trial, regardless of its original filing date, in an effort to reduce litigation costs. ${ }^{4}$ Neither those who developed the plans for the facilities nor those charged with operating them could draw upon the results of objective analyses comparing different approaches to achieving their goals. Indeed, descriptions of the discussions and debates surrounding the establishment of

Copyright $@ 1990$ by Law and Contemporary Problems

- Research Director, Institute for Civil Justice, RAND.

1. Judith Resnik has documented the long years of discussion and debate that preceded the adoption of the federal multidistrict litigation procedure and the 1966 amendments to Rule 23, as well as the more recent appellate history of class action certification for mass torts. See Judith Resnik, From "Cases" to "Litigation," 54 L \& Contemp Probs (forthcoming 1991).

2. For a discussion of courts' interests in resolving mass litigation, see Mark A. Peterson \& Molly Selvin, Mass Justice: The Limiled and Unlimited Power of Courts, 54 L \& Contemp Probs (forthcoming 1991).

3. See Marianna S. Smith, Resolving Asbestos Claims: The Manville Personal Injury Settlement Trust, 53 L \& Contemp Probs 27 (Autumn 1990). According to the FIFO rule, cases were to be processed in order of the original date of filing in court.

4. See Mark A. Peterson, Giving Away Money: Comparative Comments on Claims Resolution Facilities, 53 L \& Contemp Probs 113 (Autumn 1990). 
the facilities suggest that all of those involved felt they were creating unique institutions. ${ }^{5}$

Claims resolution facilities should not be thought of as sui generis institutions, however. These facilities operate compensation programs similar to Social Security Disability Insurance, workers' compensation, the federal Black Lung Program, and the recently created statute-based Vaccine Compensation Program. ${ }^{6}$ Like the designers and managers of those more familiar programs, those who design and manage claims facilities need to grapple with issues related to funding, eligibility rules, payment schedules, and claims screening and valuation procedures.

In this article, I propose an agenda for research on claims resolution facilities, the results of which could assist in improving the current set of facilities and fashioning better alternatives for the future. ${ }^{7}$ The objectives of the proposed research are to describe the outcomes of different facilities, to examine differences in outcomes among the facilities and between claims facilities and other compensation systems (including the tort liability system), and to develop a better understanding of the relationship between key design and implementation decisions and these outcomes. In Parts II and III of the article, I discuss the outcomes of interest and the relationships between design and outcomes that merit further investigation. In Part IV, I briefly consider the feasibility of collecting systematic empirical data on the claims resolution facilities. I conclude in Part $\mathrm{V}$ by discussing the public interest in research on claims facilities.

\section{Outcomes of Claims Resolution facilities}

Over the past decade, empirical analyses of case outcomes, transaction costs, and procedural justice have enhanced our understanding of the tort system. ${ }^{8}$ Similar research has been conducted on the outcomes of workers' compensation and auto no-fault systems, ${ }^{9}$ and on some social benefit

5. There is no evidence in descriptions of the creation of the facilities, for example, that the parties turned to studies of statutory-based compensation programs for information or ideas on program design and implementation. See these proceedings.

6. See, for example, Kenneth R. Feinberg, The Dalkon Shield Claimants Trust, 53 L \& Contemp Probs 79 (Autumn 1990).

7. The development of claims resolution facilities is one facet of the larger issue of the consequences of aggregating mass torts. My proposed research agenda does not attempt to address this larger issue. Nor does it address the question of why certain design features were adopted by each facility.

8. For examples of such analyses, see Deborah R. Hensler, Trends in Tort Litigation: Findings from Institute for Civil Justice Research, 48 Ohio St L J 479 (1987); James S. Kakalik \& Abby Robyn, Costs of the Civil Justice System: Court Expenditures for Processing Tort Cases (Inst for Civil Justice, RAND, 1982); E. Allan Lind, et al, In the Eye of the Beholder: Tort Litigants 'Evaluations of Their Experience in the Civil Justice System, 24 L \& Soc'y Rev 953 (1990).

9. For example, see Workers Compensation Research Institute, Annual Report/Research Review (1990); James K. Hammitt \& John E. Rolph, Limiting Liability for Automobile Accidents: Are NoFault Tort Thresholds Effective?, 7 L \& Pol 493 (1985). 
systems. ${ }^{10}$ Many controversies attending the design and implementation of claims resolution facilities also concern issues related to the pattern of case outcomes, transaction costs, and procedural justice. Developing comparative data on these consequences should therefore be central to our research agenda. We also need better information on how effective the facilities are in including those who are eligible for compensation under the plan and in foreclosing future litigation. Finally, judges, who must often approve the establishment and design of claims resolution facilities, should know more about claimants' responses to the facilities: how well they understand what they have to do to claim compensation; how satisfied they are with the outcomes they obtain; and whether particular classes of claimants have special problems dealing with the claims resolution process.

\section{A. Patterns of Case Outcomes}

Each claims facility was intended to produce a particular pattern of outcomes: some classes of claimants would be denied compensation entirely, and others would receive amounts determined by a combination of factors, some of which were set forth in the claims resolution plan and others of which were determined by subsequent implementation decisions. " What have been the effects of these decisions? Who wins, who loses under each plan? To answer these questions, we need to know (1) the average recovery ratios, that is, the ratio of compensation (net of attorney fees and other legal expenses) to loss; (2) the distribution of recovery ratios, by total and net economic loss, injury characteristics, sociodemographic characteristics such as income, education, race, ethnicity, and gender, and any additional characteristics that were incorporated in the rules for determining levels of payment; and (3) the timing of payment, in relation to injury onset, accrual of losses, initial date of claim, and date of creation of the facility. Average recovery ratios will enable us to determine how well the level of payment matched the intentions of the facility designers, and to compare payment patterns across facilities, and between facilities and other compensation programs. Distributional data on recovery ratios are essential to understanding the social consequences of payment plans. Many payment plans were designed to reflect the values of cases processed through the traditional tort processes, prior to claims resolution. It seems reasonable, therefore, to compare distributional data for these facilities to similar data for the tort system. Although most claims resolution plans do not link payments directly to need, from a public policy perspective, how well the programs serve claimants' needs is clearly an

10. For example, see Peter Barth, The Tragedy of Black Lung (W.S. Upjohn Inst for Employment Res, 1987); Theodore Marmon \& Jerry Mashaw, eds, Social Security: Beyond the Rhetoric of Crisis (Princeton U Press, 1988).

11. "Plan" refers to, for example, the formal document adopted to resolve the litigation, In re $A$. H. Robins, Co., The Sixth Amended and Restated Disclosure Statement Pursuant to Section 1125 of the Bankruptcy Code, No 85-01307-R (March 28, 1988). "Implementation decisions" refers to, for example, the specific provisions regarding medical records laid out in information packets sent to Dalkon Shield claimants. 
important issue. By comparing amounts received to net economic loss (that is, losses not covered by private insurance or other sources of reimbursement), we can obtain at least a crude measure of how well the payment plans met the parties' needs, independent of the strength of their legal claims. The third factor, timing of payment, is an issue of concern to any compensation program and was a particular source of controversy in designing some of the facilities. Timing of payment in relation to injury onset and loss accrual also has an obvious equity dimension.

\section{B. Transaction Costs}

Transaction costs are measured by the ratio of expenses incurred in delivering compensation to total costs of providing compensation. Analyses of the transaction costs associated with the traditional tort system usually include both sides' attorneys' fees and expenses, insurance claims' processing costs, and the operational costs of the court system. ${ }^{12}$ Similarly, to measure transaction costs of claims facilities, we need to know (1) the total expenses to operate the claims facilities, distinguishing general overhead expenses, inhouse costs to process individual claims, and fees and expenses for outside counsel and other outside consultants, and (2) the fees and expenses for claimants' lawyers. Because many claims facilities apply different approaches to different classes of claimants, it would be useful to be able to compare transaction costs for processing different classes of claims. Additionally, because claims facilities are relatively new institutions, analyses of transaction costs should consider changes in cost ratios over time.

\section{Procedural Justice}

In designing claims resolution facilities, attorneys and court officials appear to have focused more on issues of distributional justice (who should get how much, for what injuries and losses) than on issues of procedural justice (what types of claims resolution process would claimants perceive to be fair). Americans, however, as evidenced by extensive research on individuals' experiences dealing with the justice system and other public institutions, distinguish between distributional and procedural fairness. ${ }^{13}$ Litigants and clients of government programs obviously care about what they get from courts and other institutions, but they also care about how they are treated by public officials. In particular, civil litigants are more likely to feel that court procedures are fair when decisionmaking is (or appears to be) deliberative and thorough, when they themselves are treated in a dignified fashion, and when they believe they have some control over the decisionmaking process,

12. See, for example, James S. Kakalik \& Nicholas M. Pace, Costs and Compensation Paid in Tort Litigation (Inst for Civil Justice, RAND, 1988).

13. For a review of these research findings, see E. Allan Lind \& Tom R. Tyler, The Social Psychology of Procedural Justice (Plenum, 1988). 
either directly or indirectly through their legal representatives. ${ }^{14}$ Just as researchers have studied variations in perceived procedural justice among different dispute resolution procedures, we should investigate variations in procedural justice among different claims resolution facilities. ${ }^{15}$

\section{Claim Inclusion and Closure}

Claims facilities, like other aggregative procedures (such as class actions) require some means of identifying eligible claims. Ideally, the claims facility should receive claims from all legitimate claimants; it should also be able to detect and reject non-legitimate claims. In addition, most claims facility agreements seek to reduce the defendants' uncertainty about the amount they would have to pay, either by setting a ceiling for that amount (as in the Dalkon Shield agreement), by providing for a regular transfer of assets (as in the Manville Personal Injury Trust agreement), or by allocating fixed shares of damage payments among defendants (as in the asbestos claims facilities). Once these agreements have been reached, parties typically have a shared interest in precluding renegotiation or relitigation of the agreement.

Toward these ends, at the time each claims resolution facility was designed, a determination was made as to how much money would be necessary to resolve present and future claims. Estimating the ultimate number and value of claims was a source of great controversy and, in at least two cases to date, misestimation has led to an unravelling of claims resolution plans. ${ }^{16}$ Moreover, with at least one plan, there has been considerable controversy over whether all those eligible for compensation have been informed properly and will seek compensation. ${ }^{17}$ Research on claims resolution facilities therefore also should consider the number of claims received, the patterns of claims filing over time (that is, what types of claims are filed, by what types of claimants, at different stages of the claims resolution process), and the amount of aggregate payments. Comparing

14. E. Allan Lind, et al, The Perception of Justice: Tort Litigants' Views of Trial, Court-Annexed Arbitration, and Judicial Settlement Conferences 52-53 (Inst for Civil Justice, RAND, 1989) ("Views of Trial").

15. Some critics of research on procedural justice argue that findings may be an artifact of "false consciousness," that is, procedures may be designed to make litigants believe they have been treated fairly when an objective assessment would conclude the opposite. Clearly, measures of perceived fairness should not substitute for more objective measures of outcomes. Other things being equal, however, we would prefer justice systems that are believed to be fair by those they serve. For a review of the debate over the importance of perceived fairness, see id at 4-6.

16. The first asbestos claims facility disintegrated when it became clear that the pattern of claims filing was not that which had been anticipated by the participating defendants at the time they drew up their cost-sharing agreements. Lawrence Fitzpatrick," The Center for Claims Resolution, 53 L \& Contemp Probs 13, 14-17 (Autumn 1990). The Manville Personal Injury Trust plan was reopened when Judge Jack Weinstein determined that the trust could not meet ongoing requests for payment. In the Matter of Joint Asbestos Litigation, Johns-Manville Corp., Transcript of Fairness Hearings (E \& SD NY, Washington, D.C.. January 4, 1991) ("Transcript of Fairness Hearings"). See also Smith, 53 L \& Contemp Probs at 28 (cited in note 3).

17. Advocates of Dalkon Shield claimants assert that many women never received notice of the bankruptcy. See Frank Green, More than 300 late claimants of Dalkon funds show up at court, Richmond News Leader B2 (October 20, 1990). 
these data to the estimates upon which the plan was based, as well as to the other estimates that were proposed and rejected at the time the plan was developed, will provide useful indicators of the performance of claims facilities concerning inclusion. Researchers should also review the nature, costs, and outcomes of post-agreement controversies-for example, renegotiations of key issues.

To improve our understanding of the claims identification process, it may also be useful to examine data that do not derive directly from the claims resolution facilities. For example, studies of changes in the level of public information about injurious products ${ }^{18}$ and investigations of the relationship between media coverage of injury and litigation events and claims filing might suggest how the dissemination of information affects claiming propensities. Similarly, it might be useful to examine patterns of response to public notices regarding class certification and settlement, and patterns of voting on proposed bankruptcy reorganization plans.

\section{E. Claimant Response to Claims Resolution Facilities}

The goal of claims resolution facilities is to deliver compensation to individuals. Individual claimants, however, play little or no role in the design of compensation facilities and, to date, there has been no empirical research on the claimants' views of the outcomes they receive, the costs they incur, or their perceptions of the processes that determine their eligibility and amount of payment. We do not know how much claimants understand about the operations of the facilities, what is expected of them, or what they can do to influence outcomes; nor do we know what aspects of the facilities' operations they would like to know more about. We do not know how well claimants understand the information they are given about payment options, nor how good a job they do in selecting the payment option that is objectively best for them. We also do not know how important non-economic goals are to claimants, what outcomes other than monetary payments they would find desirable, or whether they would be willing to trade monetary payments for other benefits. Moreover, many claimants are members of disadvantaged groups, for example, poor Black residents of Triana, Alabama, blue-collar shipyard workers, and women. These individuals may face particular disadvantages when dealing with facilities that were designed and are operated, for the most part, by affluent, white, professional males. In discussions of claims resolution facilities-as in discussions of legal processes more generally - the voices of judges, lawyers, corporations, experts, and researchers predominate. ${ }^{19}$ Empirical studies of claimants' experiences and

18. See, for example, Herbert M. Kritzer, Public Notification Campaigns in Mass Litigation: The Dalkon Shield Case, Just Sys J 13 (1988-89).

19. We should note that none of the papers in this symposium were written by claimants or claimant representatives; nor, to my knowledge, did any of these individuals attend the conference that preceded the publication of these papers. 
attitudes would help give voice to those whose injuries were responsible for initiating the claims resolution process.

\section{III}

\section{Explaining Outcomes of Claims Resolution Facilities}

In his contribution to this symposium, ${ }^{20}$ Mark Peterson has taken a first step toward the type of descriptive analysis I propose above. His analysis is limited, however, by lack of data on many important outcomes. Moreover, at this preliminary analytic stage, Peterson cannot tell us much about why different facilities have produced different outcomes. Identifying relationships between key design and implementation decisions and facility outcomes is the most important task for public policy analysis.

Designing and implementing the claims resolution facilities required numerous decisions. In principle, each of these decisions could have had important effects on patterns of case outcomes, costs, procedural fairness, inclusion and closure, and claimant response. It would be impractical, however, to attempt to study the effects of every decision. The research agenda should therefore be shaped around a consideration of the consequences of choosing particular models of compensation delivery. Not all key decisions derive from such overarching choices, however. Below, I first outline a conceptual framework for identifying models of compensation delivery, and then discuss some additional design decisions that seem worthy of research.

\section{A. Models of Compensation Delivery}

The essential purpose of all claims resolution facilities is to give away money. The decisions made in designing and operating facilities concern how much money will be given away in total, to what people, upon presentation of what information, and according to what processing rules. There are numerous ways to answer such questions, but we can think of each claims facility, and other compensation program, as falling somewhere within a twodimensional matrix, where one dimension represents rules for determining the value of claims and the other dimension represents rules for processing claims. $^{21}$ Figure 1 depicts this matrix.

20. Peterson, $53 \mathrm{~L} \mathrm{\&} \mathrm{Contemp} \mathrm{Probs} 113$ (cited in note 4).

21. My thinking about models of compensation delivery has been informed by discussions with Elizabeth Rolph. In a forthcoming Institute for Civil Justice monograph, Rolph presents a more elaborated conceptual framework for analyzing compensation programs. Elizabeth Rolph, Designing Alternative Compensation Systems (Inst for Civil Justice, RAND, forthcoming). Peterson, 53 L \& Contemp Probs 113 (cited in note 4), presents a somewhat different conceptual framework for categorizing claims facilities. 
Figure 1

Conceptual Framework for Considering Compensation

Programs $^{22}$

\begin{tabular}{||l|l|l|l||}
\hline \multirow{2}{*}{\begin{tabular}{l} 
Claims Valuing Rules \\
\cline { 2 - 4 }
\end{tabular}} & \multicolumn{1}{|c|}{ Administrative } & $\begin{array}{c}\text { Claims Processing Rules } \\
\text { Administrative and } \\
\text { Adversarial }\end{array}$ & \multicolumn{1}{|c|}{ Adjudicative } \\
\hline $\begin{array}{l}\text { Individualized } \\
\text { Litigation Value }\end{array}$ & DDT(2) & & $\begin{array}{l}\text { Tort System } \\
\text { ACF } \\
\text { Manville Trust (I) }\end{array}$ \\
$\begin{array}{l}\text { Litigation-Based } \\
\text { Schedule } \\
\begin{array}{l}\text { Need-Based } \\
\text { Schedule }\end{array}\end{array}$ & Dalkon Shield & \\
Equal Shares & $\begin{array}{l}\text { Agent Orange } \\
\text { Workers' Compensation } \\
\text { SSDI } \\
\text { DDT(1) }\end{array}$ & & \\
\hline
\end{tabular}

Administrative systems implement strict objective rules regarding eligibility for compensation, use schedules to determine amounts to be paid to particular individuals, and process claims bureaucratically. An administrative compensation system could use any of a variety of the principles indicated in Figure 1 to determine the value of claims, including what the claims would be worth in a litigation system. In practice, most administrative systems, including the Social Security Disability Insurance System, most workers' compensation systems, and the Agent Orange facility, ${ }^{23}$ use some variant of a need-driven schedule to determine award amounts. Unlike these need-driven systems, the first DDT class action settlement divided the total award equally among class members, while the second used a schedule based on litigation values. ${ }^{24}$ The administrative model is attractive in situations where funds are limited, because payment schedules provide a means of predetermining how much will be spent (assuming the number of claimants is properly estimated). Administrative facilities are also more easily centralized, which makes it easier to monitor and, hence, control the outflow of cash.

Adjudicative systems typically employ looser, more subjective eligibility rules, determine the amounts to be paid on a case-by-case basis, and depend on an adversarial process to determine outcomes. In such systems, a neutral

22. The assignment of the various claims resolution facilities to categories is based on information presented in this symposium. SSDI refers to the Social Security Disability Insurance Program. DDT(1) refers to the first DDT class action settlement; DDT(2) refers to the second settlement, designed by Francis McGovern. For a discussion of the DDT claims resolution process, see Francis E. McGovern, The Alabama DDT Settlement Fund, 53 L \& Contemp Probs 61 (Autumn 1990). ACF refers to the asbestos claims facilities. Both the first and the current facility used litigation-values to assess claims. See generally Fitzpatrick, 53 L \& Contemp Probs 13 (cited in note 16).

23. See Harvey P. Berman, The Agent Orange Veteran Payment Program, 53 L \& Contemp Probs 49 (Autumn 1990).

24. See McGovern, 53 L \& Contemp Probs 61 (cited in note 22). 
third-party decides all cases that the adversaries cannot resolve among themselves. These third-party decisions, in turn, influence the outcomes of disputes that the parties settle themselves. The tort liability system is the quintessential example of an adjudicative system. Claims resolution facilities employing adjudicative systems try to settle cases through bilateral bargaining. When bargaining fails, however, cases revert to the traditional tort system. The adjudicative model is attractive when a premium is placed on individualized treatment of claims and claimants.

In principle, adjudicative claims resolution facilities could use a variety of rules for determining claim value. For example, if a facility adopted needbased rules, the adversaries would contest the question of how needy the claimant really was, introducing evidence on loss, family resources, and other sources of available compensation. Some compensation systems do, in fact, provide for such adjudicative contests. Social Security decisions, for example, sometimes lead to court contests on the claimants' degree of disability. ${ }^{25}$ In practice, adjudicative claims facilities such as the Asbestos Claims Facility and the Manville Trust have chosen to use a litigation-standard in determining claims values. ${ }^{26}$

Some programs are deliberately designed to mix characteristics of the administrative and adjudicative models. For example, the workers compensation system in Texas refers contested claims to the tort liability system for resolution. ${ }^{27}$ Among claims resolution facilities, the Dalkon Shield facility is an example of such a mixed approach. ${ }^{28}$ Claimants may apply for payment of fixed amounts and are assured compensation if, upon presentation of specific evidence, the claim meets minimum verification standards. Unlike DDT(2) claimants, however, who apparently lacked recourse to an adjudicative system, Dalkon Shield claimants may reject this option of scheduled payments in favor of an adversarial process that demands more extensive evidence and uses alternative dispute resolution and/or trial to determine whether and how much compensation will be paid. Although a mixed approach to claims processing could use a variety of standards, the Dalkon Shield facility appears to have based its schedule of payments upon a litigation standard. Claimants are offered less if they cannot produce documents to verify Shield use or causation, for example, because in the tort system, they would face obstacles to winning their claims without such verification. Supporters of mixed strategies presumably seek to gain the benefits of both the administrative and adjudicative models without incurring their costs.

25. Rolph, Designing Alternative Compensation Systems (cited in note 21 ).

26. Fitzpatrick, 53 L \& Contemp Probs at 21-22 (cited in note 16); Smith, 53 L \& Contemp Probs at $32-33$ (cited in note 3 ).

27. See Peter Barth, Richard Victor \& Susan Eccleston, Workers 'Compensation in Texas (Workers Compensation Res Inst, 1989).

28. Feinberg, 53 L \& Contemp Probs at 105-09 (cited in note 6). 
Because several different facilities have chosen to use the same model of compensation delivery, we have an opportunity to investigate whether outcomes are wholly idiosyncratic-that is, facility specific-or are systematically related to these overarching models.

\section{B. Other Key Decisions}

Some decisions about claims facility design and implementation do not derive directly from the choice of a particular model for compensation delivery. Among such decisions, those that seem likely to have had important effects include: (1) the claims estimation strategies; (2) the order of payments; (3) the claimant outreach procedures; (4) the establishment of a new, standalone organization rather than the employment of an existing private or public agency to deliver compensation; (5) the recruitment and staffing strategies; and (6) the roles assigned to attorneys, both those representing claimants and those acting on behalf of the facilities.

1. Claims Estimation. Some claims resolution plans, such as the Dalkon Shield plan and the DDT(2) plan, were based on quite extensive research on the size of the claimant pools and the aggregate value of claims. ${ }^{29}$ Others, such as the Agent Orange plan, ${ }^{30}$ were adopted without much information about either. Still others, such as the original Manville Plan and the first asbestos claims facility, seem to have been based on faulty data. ${ }^{31}$ Perhaps we can learn how to develop better estimation strategies and how much to invest in the estimation process by relating the nature of the estimation processes in the various claims resolution plans to the actual outcomes.

2. Order of Payments. The Manville Trust adopted a strict rule for paying claims in the order in which the associated lawsuits had first been filed. The recently announced amendment to the plan ${ }^{32}$ proposes a more complex ordering based on the severity of each claimant's exposure-related illness. Under the Dalkon Shield agreement, thousands of minimum-value Option 1 claims were processed before claimants were provided with detailed information about other payment options. In assessing claims facilities, it is important to investigate how these different approaches have affected distributional equity and plaintiffs' perceptions of fairness.

3. Claimant Outreach Procedures. The Dalkon Shield program developed and mailed to claimants elaborate sets of materials explaining the claims resolution plan and the available payment options. In a public presentation to claimants, Special Master Francis McGovern delivered a detailed

29. See, respectively, Feinberg, 53 L \& Contemp Probs at 101-03 (cited in note 6); McGovern, $53 \mathrm{~L} \&$ Contemp Probs at 64 (cited in note 22).

30. Up until several days before the $\$ 180$ million settlement was reached, participants in the Agent Orange Plan had little hard information on the number of potential claims. See Peter $H$. Schuck, Agent Orange on Trial: Mass Toxic Disasters in the Courts 161-62 (Belknap, 1986).

31. See discussion in note 16 .

32. See Transcript of Fairness Hearings (cited in note 16). 
description-complete with multicolor graphics-of the rationale and implementation plans for the DDT(2) settlement. Descriptions of the information dissemination practices and materials of other facilities are not currently available, but several facilities appear to depend on claimants' attorneys to disseminate information. Research on outreach should determine the level of claimant knowledge regarding each facility's rules and operation, and the sources claimants turn to for information.

4. Stand-alone Versus Existing Facilities, and Staffing Strategies. Only the Agent Orange facility chose to contract with a private agency for the payment of its claims rather than create a new stand-alone facility. The stand-alone facilities made rather different decisions concerning location, staffing patterns, and other administrative issues. Although we would expect these different strategies to result in significantly different transaction costs, research might reveal that they also have important consequences for patterns of payments, procedural justice, and claimant satisfaction-all of which should be explored.

5. Role of Attorneys. All current claims resolution facilities include attorneys as staff members and/or representatives of claimants. Although some facilities developed procedures to minimize the need for attorney representation, others assumed the attorneys' involvement would continue at the same levels as observed during the litigation process. What is the relationship between attorney use and claimant outcomes? Do certain kinds of claims resolution plans require the use of attorneys if claimants are to obtain the intended outcomes? Do certain kinds of claimants need attorneys to help them master the details of claiming, regardless of claims facility design? How much does attorney representation cost? How much, if at all, would claimants as a group benefit, with regard to payments received, if attorney fees were regulated? How much should claims facilities pay their counsel to represent them in litigation or other dispute resolution processes? What would be the costs and benefits of regulating their fees? Because attorneys serve a central role in the claims resolution process, these are very sensitive questions. From a public policy perspective, however, if claims resolution facilities are to be substituted for the traditional litigation process, it appears appropriate to try to answer them.

IV

The Feasibility of Conducting Research on Claims RESOlUtion Facilities

Conducting detailed analyses of the type outlined in this article will be expensive and time consuming. But the research that has already been conducted while designing the facilities indicates that it is possible to carry out such studies. At least two of the claims resolution plans described in this 
symposium, the Dalkon Shield Plan and the DDT(2) plan, ${ }^{33}$ were derived after extensive data collection and analysis spearheaded by the special master, including, in the latter case, claimant interviews. As part of their efforts to resolve asbestos litigation, the federal district courts in Eastern Texas and Northern Ohio have mandated similar data collection and analysis efforts. ${ }^{\mathbf{3 4}}$

The data collection methods and forms that were developed for these efforts could be modified to collect information about case outcomes from the facilities' claims files. Some components of transaction costs also should be available from the facilities' administrative records. Because procedural justice and claimant satisfaction are subjective concepts, however, studies of these aspects of the claims resolution process will require surveys of individuals. It would be relatively easy to adapt the approach that has been used in studying litigants' perceptions of traditional tort processes to study claimants' experiences with claims resolution facilities. These surveys would also yield additional data on transaction costs and outcomes.

The key question concerning feasibility is whether those who maintain the relevant databases will choose to cooperate. Because the facilities are essentially private institutions, they need not provide access to their data, and there are several reasons why they might not wish to do so. First, the research would disrupt ordinary bureaucratic processes: business would be interrupted as the analysts searched administrative records and machinereadable data bases, and talked to key personnel about facility operations. Second, data on individual case characteristics and outcomes are private, raising issues of confidentiality. Even providing the claimants' names to survey researchers might be viewed as a breach of confidentiality. Finally, research findings might change claims filing patterns and negotiation strategies. For example, if claimants and their representatives knew what the average claim payment was, they might be less inclined to settle for an amount less than the average. Many legal practitioners believe that the negotiation process benefits from uncertainty regarding outcomes.

Research techniques have been developed for dealing with the first two of these concerns. Survey analysts experienced in the use of public and private administrative data have developed procedures for minimizing the burden such research operations place on administrative staffs. Most large-scale surveys conducted for public policy purposes are regulated by statutes and/or rules that prohibit disclosure of participants' identities and require security measures to protect private data, whether in computer-readable or hard-copy form. Survey researchers have a repertoire of procedures for deleting names and other identifying information from interviews before data are transformed into machine-readable form, destroying identifiable hard-copy records, and the like.

33. See, respectively, Feinberg, 53 L \& Contemp Probs at 101-03 (cited in note 6); McGovern, $53 \mathrm{~L} \&$ Contemp Probs at 64 (cited in note 22).

34. See Francis E. McGovern, Toward a Functional Approach for Managing Complex Litigation, 53 U Chi L Rev 440, 480 (1986). 
The third concern, that systematic information about outcomes will somehow impair facility performance, is more troublesome. The claims resolution plans are based upon certain assumptions about claimants' and attorneys' behavior. If these behaviors change, a plan could prove unworkable. On the other hand, in the past decade we have all learned more about the outcomes of the tort liability system, but I am not aware of any published statements arguing that this knowledge has significantly changed behavior. Moreover, it seems unlikely that claimants' representatives are so ignorant of the pattern of payments that aggregate statistical analyses of the facilities' consequences would dramatically change their negotiation strategies.

When to conduct such research is clearly an issue. Because some facilities are intended to operate for many years, waiting until all claims have been paid is impractical if our purpose is to inform decisionmaking in the near term. Collecting data on long-past events is also difficult, because records may be destroyed or archived in hard-to-access facilities, and because memories fade. On the other hand, initiating research too early in the implementation process would be disruptive and might yield misleading results. My suggestion would be to design-in a capacity for the type of research I have proposed, for example, by insuring the retention of key data, but delay research until the program has stabilized. Thereafter, one might conduct periodic studies of the facilities as they progress.

\section{$\mathrm{V}$ \\ Conclusion}

Claims resolution facilities have played, and probably will continue to play, a key role in resolving protracted mass litigation and delivering compensation to claimants. Although the facilities are not themselves public institutions, they have been created, for the most part, under the aegis of the courts. In return for accepting compensation from claims resolution facilities, claimants either give up their rights to civil trials or accept restrictions on these rights. Judges who are asked to approve claims resolution plans in class action settlements, bankruptcy reorganization plans, and other aggregative procedures for mass torts should know more than we currently can tell them about how these facilities affect patterns of payment, costs, and procedural justice, how well they identify and serve legitimate claimants, and about whether such facilities will indeed succeed in closing off future litigation. Claims facility designers and managers of the future should know more about how different design options will affect outcomes, costs, and perceptions of fairness, and about how specific plan features influence claimant understanding of and response to payment and procedural options. Research of the type I propose in this article has been conducted in the public court system for many decades. Working together in that context, judges, court administrators, attorneys, and researchers have designed projects that properly protect due process and citizens' privacy rights, and that have 
contributed to improving the efficiency and equity of dispute resolution. By beginning to collect and analyze the types of data I have identified here, we can help improve future decisionmaking about the aggregative resolution of mass torts. 